instrumentation side, certain techniques, such as gel electrophoresis, which are central to the new methods of molecular biology, may be singled out for increased attention; but Philipson is also said to have shown his support for the great efforts being made at Heidelberg to improve electron microscopy through cooling the microscope and specimen (see accompanying box).

At present Sir John Kendrew is still firmly in charge. He foresees an increase in the number of permanent scientific appointments (still less than a handful) at the laboratory in the next couple of years, as a batch of the early short-term contracts come to an end. Philipson, however, has made no commitments. As for Sir John himself, he feels that the seven years and three months for which he will have held the directorship is quite long enough.

Robert Walgate

\section{Polish crisis}

\section{Science in limbo}

The "state of war" proclaimed by General Jaruzelski's "Military Council for National Salvation" has brought all academic life in Poland to a standstill. The universities are closed as are several institutes of the academy of sciences. Scores of scientists and scholars have been arrested although some, such as the president of the academy, Dr Aleksander Gieyszter, have since been released. Others escaped arrest only by chance, being away from home when the police came, and are now in hiding. Solidarity organizers in the learned professions and activists from the Independent Students' Association have been interned. The Minister of Science, Higher Education and Technology, Dr Jerzy Nawrocki, is reported to have resigned.

This clamp-down on intellectuals is in sharp contrast with Jaruzelski's previous attitude. In a recent interview, Dr Leonard Sesnewski, one of the vice-presidents of the academy, said that Jaruzelski had always expressed warm feelings for scientists and that, on taking of fice as prime minister last February, he had immediately visited the academy to ask for their help in getting Poland out of its economic crisis.

Nevertheless, the growing drive for academic autonomy must have caused a certain friction between the general and the academy. At present, the academic secretary of the academy holds quasiministerial rank, and is responsible to the prime minister. In recent months, however, there has been considerable pressure from academy members and employees to incorporate into the proposed new bill on the academy clauses that would terminate this structure and make the academic secretary responsible only to his fellow-academicians. There has also been a drive - reflected in the Solidarity Congress resolution on learning and culture - to break down the barriers between the universities and the academy, so that academy employees could deliver lectures to undergraduates. This trend may have seemed dangerous to the authorities; a number of scholars, expelled or excluded from teaching posts for their political views over the past few years, have found a safe haven in academy research posts insulated from teaching.

For the time being, the concern of scholars abroad is focused on the plight of their Polish colleagues interned or in hiding. Professor Olof Tandberg and his colleagues from the Swedish Academy of Sciences (which traditionally has strong links with Poland) and several members of the Norwegian Academy have launched an appeal for financial support for the families of interned academics. Professor Tandberg has also received an appeal from a group of academy scholars in hiding asking for food, blankets and other essential supplies, including blood plasma. $\mathrm{He}$ has called on all other academies throughout the world to join the Norwegian and Swedish academics in this work.

Vera Rich

\section{UK agricultural research Endangered duo}

Two British agricultural research institutes, the Long Ashton Research Station in Bristol and the Animal Breeding Research Organisation in Edinburgh, could be drastically cut or even closed if an economy proposal by the Agricultural Research Council is approved at its next meeting in February. Under threat are all research programmes at the Edinburgh institute except work on fundamental animal genetics, and the Pomology and Food and Beverages Division at Long Ashton.

The council (ARC) hopes the closures will save about $£ 3$ million in annual expenditure by 1983-84. (The budget for 1981-82 is £86 million.) According to $\mathrm{Dr}$ Ralph Riley, the secretary of ARC, the savings are needed both as a hedge against future government cuts and to allow greater flexibility in supporting research of high priority. The council's research programme has already suffered, he says, from a budget that has not kept up with inflation. Non-payroll expenditure has already been pared to the bone. But precisely how much of the $£ 3$ million saved will be available for starting new research projects after cuts in income are taken into account remains uncertain.

If the proposal is approved, the Long Ashton Research Station will be reduced to about one half of its present strength, with the loss of about 100 jobs. The Animal Breeding Research Organisation, however, will probably be closed and the research on animal genetics, which accounts for about one-fifth of the organization's activity, moved elsewhere.

ARC has made the proposal without consulting the staff or directors of the institutes concerned, who first learnt of it only last week. The idea, according to Dr Riley, was for ARC to propose firm suggestions for savings and then to give those concerned two months in which to make a case before a final decision. The way in which the proposal was arrived at remains something of a mystery, but the main criterion seems to have been an assessment of priorities based on recent reviews of the work of all the council's institutes. Areas in which the council is likely to want to spend more money include fundamental genetics and biotechnology.

If approved, the proposal could have implications for the Ministry of Agriculture, Fisheries and Food, which spends about $£ 44$ million a year in ARC institutes on commissioned research. The ministry is optimistic that the work it commissions in the institutes under threat could be transferred to other institutes. Dr Riley, however, believes that this will be possible for most commissioned research but that there may be some areas where the ministry will have to look elsewhere. Judy Redfearn

\section{High-energy physics \\ LEP marches on}

The large electron-positron ring is on the move - in more than one sense. LEP will be the next big accelerator at CERN, the European Centre for Nuclear Physics, Geneva, and last week CERN member states finally agreed on the budget under which it will be built. Thus construction can begin as soon as local environmental approval is granted - by January or February, it is hoped. The second move is physical: LEP is to be built in a significantly new position, on a slope, which allows it to slide out of some tricky geological and political problems.

The budget agreed is sufficient, says CERN director-general Professor Herwig Schopper, to build LEP on the schedule foreseen a few months ago: fast enough to give colliding electron and positron beams of sufficiently high energy to provide physicists with copious neutral intermediate vector bosons by the end of 1987 .

LEP is expected to cost SF910 million (about $£ 263$ million) at 1981 prices, with a further SF40 million (making a total of $£ 275$ million) for the first experiments. The money will be drawn from a guaranteed CERN annual budget of SF617 million.

The only major argument at the council was over what inflation index to apply to the 1981 budget to scale it up to 1982 prices. The usual CERN formula, appropriately weighted for CERN's Swiss salaries and expenditure abroad, gave 5.7 per cent. The council quibbled, and agreed on 4.4 per cent, losing CERN over $£ 2$ million next year.

The new slope for LEP (it was to have been horizontal) will be about 1.5 per cent from the Jura Mountains in the north west, towards Geneva. This enables the machine 
to be slipped away from the cavernous Jura limestone, and further into the stable sandstone of the valley, in which all previous CERN accelerators have been built.

The result is that only $3 \mathrm{~km}$ (as opposed to $8 \mathrm{~km}$ previously) of the $27 \mathrm{~km}$ tunnel for LEP will be in the unpredictable limestone. Moreover, at the Jura side the ring will be higher - about 140 metres below the surface - so that if any difficult waterfilled caves are encountered, it will be possible to deal with them from above.

A further - and far from negligible benefit may prove to be political. There has previously been vociferous environmental opposition to LEP from the French side (the Jura; LEP straddles the French-Swiss border). This opposition rested in large part on the (distributed) effect that the limestone borings might have on the source and flow of the River Allondon, which supplies water to a number of villages. The source was to have been within the LEP ring; now it is outside, and where the ring passes under the river it is within stable sandstone.

LEP will be paid for out of the current budget only by running down certain existing facilities. The intersecting storage rings for protons and other nuclei will be closed at the end of 1983; and operations on the $600-\mathrm{MeV}$ synchrocyclotron (CERN's first accelerator) will be reduced to the mainly Scandinavian Isotope Separator On-Line (ISOLDE), which performs unique experiments on shortlived muclei and, incidentally, keeps the Nordic countries happy. Robert Walgate

\section{UK university funding \\ No reprieve}

The British government is sticking to its guns over cuts in university grants, indicating that universities have failed to convince the government that spreading the cuts over five instead of three years would cost less because compulsory redundancies, involving large compensation payments, would be avoided. Last week, Sir Keith Joseph, Secretary of State for Education and Science, reaffirmed his belief that the cost to the taxpayer will be less if the cuts are implemented quickly.

Hence, it is no surprise that the universities' recurrent grant for 1981-82 has been set broadly in line with the government's expenditure plans of last April. The grant at $£ 995$ million will be only $£ 16$ million more than the estimate, to account mainly for an inflation rate higher than expected. The research councils, however, may have come off slightly better than feared. At $£ 478$ million, the science vote for 1982-83 will be roughly in line with this year's figure, although the allowance for increases during the year is only 5.5 per cent.

Despite his rejection of the universities' argument, Sir Keith has nevertheless accepted that the cost of redundancies cannot be met out of the universities' recurrent grant. But his allocation of $£ 50$ million in 1982-83 for restructuring the university system has already met with derision from the Committee of ViceChancellors and Principals which says that the sum is far too small. The vicechancellors also fear that if the 5.5 per cent inflation allowance cannot be met then the number of redundancies will increase. A sum for restructuring in 1983-84 will be announced some time next year.

Sir Keith expects to reach a decision early in the new year on the scheme proposed by the vice-chancellors' committee for compensating redundant academics. Academics who take their cases to court, however, could be awarded considerably more than indicated under the scheme, making it almost impossible at present to estimate the total redundancy bill.

Advanced higher education has fared worse than any other sector of education under the government's cutbacks. The overall reduction in the education budget next year compared with this is one per cent, with further education for nonacademic school leavers winning increased support. Clearly, the universities have lost out to the much stronger voice of the growing numbers of unemployed.

Judy Redfearn

\section{Recombinant DNA research EEC safety dispute}

\section{Brussels}

A deep division of opinion has become evident among the EEC's institutions over the need for strict legal controls to minimize the dangers of research using recombinant DNA techniques. By a narrow margin, the European Parliament's Committee on the Environment, Public Health and Consumer Protection came out against the EEC going further than merely making recommendations on the registration of all relevant research. However, following a colloquy held in May (see Nature 21 May, p.181) the Economic and Social Committee (ESC) is strongly advocating that the European Community adopt a legally binding text enforcing tight safety controls.

Both opinions will be taken into acount by the ultimate decision-makers in the Committee of the Permanent Representatives to the EEC (Coreper) whose experts have been awaiting the views of the two consultative bodies.

The issue has been subject to an unusual amount of debate. In 1979 the European Commission itself proposed a legally binding directive along the lines demanded by ESC. This was then withdrawn and replaced by a set of recommendations to take account of evidence and scientific opinion which increasingly suggests that the dangers from bioengineering are less than were at first feared.
ESC thinks that the recommendations are too weak and that the reasons put forward to justify the original draft directive still hold good. It still considers that in the long term the unforeseeable and potentially serious consequences of recombinant DNA work require a "better safe than sorry approach", especially when pathogens are used as vectors or hosts. Also, the EEC has a responsibility to ensure that competition for commercially applicable research is not distorted by different rules on what can be done, and at what speed, in each member state.

The colloquy held by ESC to debate these points failed to budge the committee from its opinion, although many of the speakers there affirmed that the risks associated with genetic manipulation are small or negligible. The committee, however, remains convinced that transferring the techniques from laboratory to factory will not mean lower safety standards. Official guidelines would, therefore, be better than a system of selfregulation.

The report produced by Italian EuroMP Domenico Ceravolo for the parliament echoes many of these concerns, but his resolution in favour of a directive was overturned in the committee vote by a majority of only one. In his report, Ceravolo attacks the European Commission's view by saying that even if a risk is only based on a hypothetical chain of events, this is no justification for thinking it any less valid or significant. And he argues further that the conjectural risks cannot be dismissed because no suitable criteria are available for assessing them.

Whether his arguments will win the day in the parliament's plenary session remains to be seen. A full vote was postponed at the last minute on 18 December but the vote is expected to go against Ceravolo. The liberals and conservatives, who form the majority in the house, support the Commission and feel that too much legislation will slow down the growth of Europe's biotechnology industry. The socialists and communists disagree and take their cue from the Italian left wing which sees EEC legislation as the best way of bringing Italian research under control.

Jasper Becker

\section{Electronic publishing Journal plugs in}

The British experiment to explore the feasibility of electronic scientific communication is well under way. The experimental electronic journal of the Universities of Loughborough and Birmingham, Computer-Human Factors, has received 16 papers in its first year more than an earlier experiment in the United States received in its three-year life. Last week, the British Library, which is backing the experiment with $£ 256,000$, organized a demonstration for publishers, 